\title{
PANDANGAN AL-GHAZALI MENGENAI PENDIDIKAN AKLIAH (TINJAUAN TEORETIS DAN FILOSOFIS)
}

\author{
Naufal Ahmad Rijalul Alam \\ (Universitas Muhammadiyah Yogyakarta)
}

\begin{abstract}
Abstrak:
Artikel ini bertujuan untuk menjelaskan pandangan Al-Ghazali mengenai pendidikan akliah dalam Islam. Dalam pandangannya, Islam memberikan penghargaan yang tinggi terhadap akal. Banyak dari ayat Al-Qur'an dan Hadits Nabi yang menganjurkan dan mendorong manusia untuk mempergunakan akalnya dan banyak berpikir guna mengembangkan intelektualnya. Merujuk kepada ayat-ayat Al-Qur'an yang di dalamnya terdapat berbagai kata seperti dabbara, nazara, faqiha, tafakkara, 'aqala, Al-Ghazali mengkaitkan kegunaan akal dengan kekuatan daya pikirnya. Pendekatan yang digunakan berbasis teoritis dan filosofis, dengan merujuk kepada ayat Qur'an yang berkaitan dengan keunggulan akal dalam skala makro berpikir manusia, serta pendapat para tokoh. Hasil dari pembahasan didapatkan, bahwa akallah yang menemukan isyarat-isyarat ilmu pengetahuan yang dalam tahap selanjutnya dapat memperkokoh keimanan, keyakinan dan ketakwaan kepada Allah SWT. Akal adalah sumber ilmu pengetahuan, teknologi dan kebudayaan yang dipergunakan untuk menciptakan alat-alat yang berguna dan menghadapi problem-problem manusia. Al-Ghazali menghendaki perkembangan akal, disamping ingin menjauhkan manusia dari manusia yang individualis, materialis dan pragmatis. Beliau menghendaki adanya keseimbangan antara kemajuan akal dan penghayatan spiritual, keseimbangan antara kegunaan dan kebenaran, sehingga pendidikan yang dicapai tidak hanya memiliki, tetapi juga memuat azas tanggung jawab kepada Tuhan, pencipta akal.
\end{abstract}

Kata Kunci: Pendidikan, Akliah. 


\begin{abstract}
:
This article aims to describe the view of Al-Ghazali on the nonsensical education in Islam. Al-Ghazali argues that Islam gives high appreciation of reason. Many of the verse of the Qur'an and the Hadith of the Prophet who was advocate and encourage people to use their minds and a lot of thinking to develop intellectually. Referring to the verses of the Qur'an in which there are various words such as dabbara, nazara, faqiha, tafakkara, 'aqala, Al-Ghazali linking usability sense with the power of thought. The approach based on the theoretical and philosophic, with reference to the Qur'anic verses related to the sense of excellence in the macro-scale human thought, and scholars' opinion. The conclusion of this article, intellect which find cues science in the later stage can strengthen faith, belief and devotion to God Almighty. Intellect is the source of science, technology and culture which are used to create tools that are useful and faced with the problems of man. Al-Ghazali requires the development of reason, in addition to want to keep people from the man individualist, materialist and pragmatic. He calls for a balance between progress and appreciation of spiritual sense, a balance between usability and truth, then education is achieved not only have, but also includes the principle of responsibility to God, the creator of sense.
\end{abstract}

\title{
Keywords: Education, non-sensical.
}

\section{A. Pendahuluan}

Pendidikan sebagai sebuah proses dalam pembentukan skill manusia melibatkan beberapa komponen. Menurut Al-Ghazali, komponen-komponen yang ada dalam proses pendidikan tersebut adalah tujuan pendidikan, subyek didik, kurikulum pendidikan, metodologi pengajaran dan evaluasi pendidikan. Pendidikan dapat dipandang sebagai wujud praktek dari pemikiran falsafi, sedangkan filosuf berjalan mengikuti alur pemikirannya. Al-Ghazali merumuskan tujuan pendidikan secara umum, yaitu untuk menyempurnakan manusia, yakni manusia yang hidup bahagia dunia dan akhirat. ${ }^{1}$ Maka dari itu, sikap Al-Ghazali yang ingin menyeimbangkan antara kedudukan akal dan spiritual dapat dipahami sebagai keinginan untuk membebaskan paham sekular yang hendak memisahkan agama dari urusan duniawi manusia karena agama dianggap hanya akan memundurkan perkembangan intelektual manusia. Oleh sosiolog modern paham itu diartikan sebagai "pembebasan manusia" dari sikap religius. ${ }^{2}$ Seiring dengan kajian Al-Ghazali tentang ajaran yang dianut oleh para pengikut aliran

\footnotetext{
${ }^{1}$ Al-Ghazali, Ihya 'Ulümiddin, Juz I, II, III, IV, Isal Ba<biyul Hilbi wa Syirkah. tt. 82.

${ }^{2}$ Ali Ashraf, Horison Baru Pendidikan Islam, (Jakarta: Pustaka Firdaus, 1989), 17.
} 
tertentu, beliau memegang erat prinsip yang bersumber dari ajaran Islam, yaitu bahwa manusia lahir tanpa membawa madzhab atau aliran-aliran tertentu. Dia lahir dalam keadaan fitrah, kedua orang tuanyalah yang kemudian mempengaruhinya untuk menjadi pemeluk Yahudi, Nasrani, Majusi atau menjadi pengikut madzhab serta aliran tertentu. ${ }^{3}$

Dengan demikian nampaklah bahwa Al-Ghazali adalah seorang yang sangat menghargai perkembangan akal. Dari pada itu Al-Ghazali menjelaskan bahwa; "Akal merupakan sumber ilmu pengetahuan, terbit dan sendi-sendinya. Dalam ilmu pengetahuan semua bersumber dari akal, sebagaimana buah-buahan yang berasal dari pohon, sinar atau cahaya dari matahari dan penglihatan dari mata".4

Secara lugas Al-Ghazali menjelaskan empat definisi akal dengan penjelasan yang bertingkat. Pertama, akal adalah sifat pembeda antara manusia dan binatang. Kedua, pembeda antara hal yang mungkin dan tidak mungkin, yang baik dan tidak baik. Ketiga, hakikat untuk memperoleh pengetahuan dari pengalaman dengan berlangsungnya berbagai keadaan. Keempat, hakikat akal adalah puncak kekuatan tahammus (semangat) untuk mengetahui akibat dari segala persoalan dan mencegah hawa nafsu sekaligus sebagai pengendali syahwat.

Dengan demikian jelaslah bahwa pengertian akal sangat luas dan bertingkat-tingkat sesuai dengan perkembangan akal pikiran manusia dan usaha pengembangannya, yakni hakikat akal yang pertama dan kedua adalah "tabiat", sedangkan akal yang ketiga dan keempat "diusahakan" pengembangannya secara optimal. Perbedaan manusia dari segala binatang atau makhluk selain manusia adalah bahwa manusia memiliki kemampuan untuk memperoleh ilmu pengetahuan dan meneruskan kepada generasi berikutnya melalui pendidikan dan pengajaran, sebagaimana Prof. Dr. Azyumardi Azra ${ }^{5}$ menyadur perkataan AlGhazali:

\begin{abstract}
"Sekalipun manusia itu termasuk dalam golongan hewaniyyah baik dalam arti luas maupun mendalam, akan tetapi dia sebenarnya mempunyai dua sifat keadaan yang sangat menakjubkan bagi dirinya, yaitu ilmu dan kemauan, yang dimaksud dengan ilmu di sini adalah kekuatan untuk membina mempunyai daya cipta yang tidak bisa diraba dan memiliki hakikat kecerdasan, kemauan atau kehendak, yang dimaksud di sini adalah nafsu, keinginan yang kuat untuk mencapai tujuan setelah diputuskan oleh pertimbangan akal yang sehat tentang segala akibatnya".
\end{abstract}

\footnotetext{
${ }^{3}$ Al-Ghazali, Al-Munqidh min Al-Dalāl, (Istanbul: Darussefaka, 1981), 3.

${ }_{4}^{4}$ Zainuddin, Seluk-Beluk Pendidikan dari Al-Ghazali, (Jakarta: Bumi Aksara, 1991), 118.

${ }^{5}$ Azyumardi Azra, Esei-Esei Intelektual Muslim \& Pendidikan Islam, (Jakarta: Logos, 1999), 119.

Jurnal Pendidikan Agama Islam

Volume 3 Nomor 2 November 2015

ISSN: 2089-1946

Hal. 348 - 367
} 


\section{B. Manusia dan Akal}

Beralih kepada kajian tentang manusia sebagai makhluk yang tidak terlepas dari aspek pendidikan bahwa manusia dengan berbagai aktifitasnya dalam pendidikan bertolak dari konsep; "Pada dasarnya manusia itu disebut Homo Educandum, yaitu makhluk yang harus dididik, oleh karena itu manusia juga dikategorikan sebagai Animal Educable, yang berarti sebagai makhluk (sejenis binatang) yang dapat dididik, karena manusia mempunyai akal, mempunyai kemampuan untuk berilmu pengetahuan atau disebut Homo Sapiens, di samping manusia juga memiliki kemampuan untuk berkembang dan membentuk diri sendiri atau self forming". ${ }^{6}$

Seperti halnya fungsi fisik yang lain, akal telah menjadi obyek teka-teki filosofis semenjak zaman Yunani Kuno sekitar 300 tahun SM hingga sekarang, namun belum menghasilkan sebuah rumusan yang pasti mengenai pengertiannya. Justeru persoalannya semakin rumit dengan munculnya istilah lain seperti intelek, rasio, kecerdasan, penalaran, otak dan pikiran. Setelah terjadi silang pendapat yang tak jelas ujungnya, lahirlah pandangan dikotomis bahwa intelek lebih mengacu kepada kecerdasan berpikir dan menghafal, sementara rasio cenderung dikaitkan dengan penalaran yang logis untuk menghadapi persoalan hidup yang rumit.

Menurut Islam, intelek dan rasio bukanlah dua substansi yang berbeda. Baik intelek maupun rasio, keduanya tercakup dalam pengertian "akal". Seseorang yang akalnya sempurna, di samping mampu berpikir secara cepat dan tepat, sekaligus juga bisa memecahkan setiap persoalan atas dasar kaidah logika yang lurus, runtut dan sistematis. Dari sanalah, akal secara etimologis mempunyai arti "ikatan".

Dalam Islam, akal merupakan salah satu hidayah dari Allah SWT yang diberikan kepada manusia yang menempati posisi kedua tertinggi setelah hidayah wijdani (perasaan) dan hawas (panca indera) sebelum hidayah yang paling tinggi, yakni din (agama) sebagai pembimbing dari semua hidayah tersebut.8Keempat hidayah tersebut adalah saling melengkapi antara satu dengan lainnya. Adapun akal sendiri, diberikan oleh Allah SWT kepada manusia yang sejatinya adalah makhluk sosial, makhluk yang saling membutuhkan. Tidaklah cukup bagi manusia untuk hidup hanya dengan perasaan dan panca indera.

Manusia sebagai khalifah yang dikehendaki Allah SWT untuk memakmurkan alam dan mengemban amanat risalah serta menegakkan segala

6Zakiah Daradjat, dkk., Ilmu Pendidikan Islam, (Jakarta: Bumi Aksara, 1992), 97.

${ }^{7}$ Hanafi Anwar, Imam Al Ghazali; Hikmah Berpikir, (Gresik: Putra Pelajar, 1998), 16.

8Umar Bakri, Tafsir Madrasy Juz 1, (Ponorogo: Percetakan Darussalam Gontor, 2000) 8. 
amal yang mengandung kemaslahatan, kebaikan dan kebenaran, tentunya dibekali dengan potensi yang diciptakan baginya. Demikianlah khalifah ditugaskan untuk senantiasa menjalankan syari'at Allah dan mengemban amanat yang dipikulkan padanya, maka jika dia (manusia) tidak melaksanakan tugas tersebut, secara langsung maupun tidak dia telah mengikuti syahwatnya dan menjadi perusak di bumi ini.

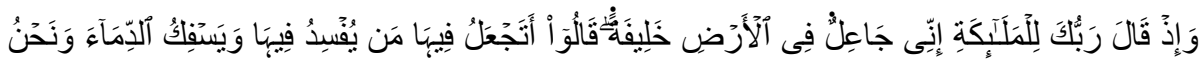

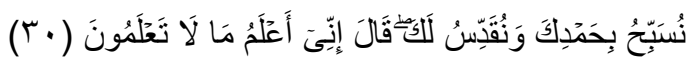

"Ingatlah ketika Tuhanmu berfirman kepada para malaikat: "Sesungguhnya Aku hendak menjadikan seorang khalifah di muka bumi." mereka berkata: "Mengapa Engkau hendak menjadikan (khalifah) di bumi itu orang yang akan membuat kerusakan padanya dan menumpahkan darah, padahal kami senantiasa bertasbih dengan memuji Engkau dan mensucikan Engkau?" Tuhan berfirman: "Sesungguhnya Aku mengetahui apa yang tidak kamu ketahui". ${ }^{9}$

Adapun yang menjadi poros khilafah manusia adalah penggunaan akal, pengemban tugas-tugas samawi serta pelaksanaan amanah yang ditempuh melalui jalur ilmu yang dipelajarinya, realisasi pemahaman serta pembedaan antara yang baik dan buruk. Dengan ini nampak jelas kelebihan manusia dibanding dengan makhluk lainnya, sekalipun malaikat, karena mereka (malaikat) hanya sekedar menjalankan perintah tanpa didasari pertimbangan dan pemikiran. Sedangkan manusia adalah makhluk yang dipersiapkan untuk berpikir dan memikul tanggung jawab serta amanah.10

Oleh karena itu, manusia berhak mendapatkan bentuk yang sebaikbaiknya dalam penciptaan, baik lahir maupun batin dengan rancangan yang indah dan struktur yang tiada banding.

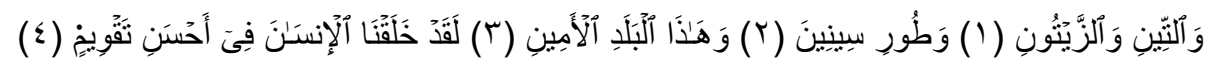

"Demi (buah) Tin dan (buah) Zaitun. Dan demi bukit Sinai. Dan demi kota (Mekah) ini yang aman. Sesungguhnya Kami telah menciptakan manusia dalam bentuk yang sebaik-baiknya".11

\footnotetext{
Insani Press, 1998), 41.

11 Terjemah Al-Qur'an Al-Jumanatul ..., At-Tiin: 1-4

Jurnal Pendidikan Agama Islam

Volume 3 Nomor 2 November 2015

ISSN: 2089-1946

Hal. 350 - 367
}

${ }^{9}$ Terjemah Al-Qur'an, Al-Jumanatul Ali, CV. Penerbit J-Art, 2004, QS. Al-Baqarah: 30

10 Yusuf Qardhawi, Al-Qur'an Berbicara tentang Akal dan Ilmu Pengetahuan, (Jakarta: Gema 
Menurut Abu Bakar Ibnu Thahir, ayat di atas menerangkan bahwa manusia diciptakan dengan dihiasi akal yang mampu menjalankan perintah, mempunyai potensi untuk dididik, memiliki bentuk tubuh yang bagus dan mendapatkan makanan dengan tangannya sendiri. ${ }^{12}$ Semua sifat itu mengisyaratkan bahwa manusia bukan hanya sekedar makhluk biologis, melainkan lebih tampil sebagai mahluk yang berbudaya. Bentuk tangannya yang dapat menggenggam, menyadarkan manusia yang sadar akan alat dan mampu menggunakan alat. Dengan akalnya dia mampu berpikir, dengan artikulasinya yang kaya dan fasih, dia mampu berbicara dengan kemampuannya berkehendak, dia mampu menyadari masa depan. Semua sifat inilah yang memungkinkan manusia untuk dapat dididik. ${ }^{13}$

Dengan tidak terlepas dari pernyataan-pernyataan di atas, penulis memberikan definisi kepada akal sebagai daya dan kekuatan yang mampu membeda-bedakan antara yang baik dan buruk, kekuatan untuk menganalisa dan memahami kejadian-kejadian di sekitar, kekuatan untuk mencipta, kekuatan untuk mengetahui sebab dan akibat, kekuatan untuk mencegah hawa nafsu dan kesanggupan untuk menerima pengetahuan yang kesemuanya itu terdapat dalam diri manusia. Sedangkan bagi hewan, akal hanyalah sebuah insting ataupun naluri untuk mempertahankan kehidupan.

Kaum teolog Islam mengartikan akal sebagai daya untuk memperoleh pengetahuan. Di samping memperoleh pengetahuan, akal juga mempunyai daya untuk membedakan antara kebaikan dan kejahatan. Dalam pengertian Islam sendiri, yang dimaksud dengan akal bukanlah otak, tetapi adalah daya berpikir yang terdapat dalam jiwa manusia, daya yang seperti digambarkan dalam AlQur'an, memperoleh pengetahuan dengan alam sekitarnya. Akal dalam pengertian inilah yang dikontraskan dalam Islam dengan wahyu yang membawa pengetahuan dari luar diri manusia, yaitu dari Tuhan. ${ }^{14}$

Menurut penulis, makna tingkatan-tingkatan akal pada manusia berarti tingkat kercedasan (inteligensi) manusia itu sendiri. Menyadur sebuah pendapat yang ditulis oleh Abu Ahmadi dan M. Umar dalam buku Psikologi Umum, ${ }^{15}$ penulis mencoba mendeskripsikan bahwa inteligensi pada manusia terbagi menjadi empat, yaitu:

a. Inteligensi terikat, yaitu inteligensi suatu makhluk yang bekerja dalam situasisituasi pada lapangan pengamatan yang berhubungan langsung dengan kebutuhan vital yang harus segera dipuaskan. Dalam situasi yang sewajarnya

\footnotetext{
${ }^{12}$ Abul Fattah Jalal, Azas-Azas Pendidikan Islam, (Bandung: CV. Diponegoro, 1988), 46.

${ }^{13}$ H. M. Arifin, Filsafat Pendidikan Islam, (Jakarta: Bumi Aksara, 2000), 58.

${ }^{14}$ Nasution, Harun, Kedudukan Akal dalam Islam, (Jakarta: Idayu, 1988), 13.

${ }^{15}$ Ahmadi, Abu dan Umar, M. Psikologi Umum (edisi revisi), (Surabaya: PT Bina Ilmu. 1990), 21.
} 
boleh dikatakan tetap keadaannya, maka dikatakan terikat. Perubahan mungkin akan dialami, kalau perbuatannya senantiasa diulang kembali. Misalnya inteligensi anak-anak yang belum berbahasa.

b. Inteligensi bebas, yaitu inteligensi yang terdapat pada manusia yang berbudaya dan berbahasa. Dengan inteligensi bebasnya, orang ingin selalu mengadakan perubahan-perubahan untuk mencapai suatu tujuan. Jika tujuan tersebut telah dapat dicapai, dia ingin mencapai tujuan lain yang lebih tinggi dan maju.

c. Inteligensi mencipta, yaitu kesanggupan untuk menciptakan tujuan-tujuan baru dan mencari alat-alat yang sesuai guna mencapai tujuan tersebut. Inteligensi ini juga disebut dengan inteligensi kreatif.

d. Inteligensi meniru, yaitu kemampuan menggunakan dan mengikuti pikiran atau hasil penemuan orang lain, baik yang dibuat, diucapkan maupun yang ditulis.

Begitu tingginya kedudukan akal bagi manusia sehingga mempunyai banyak peran yang begitu berarti bagi perkembangan manusia itu sendiri. Agama Islam sendiri memandang akal mempunyai banyak fungsi bagi kehidupan manusia. Dalam bukunya16, Abul Fattah Jalal mengutip pendapat Syaikh Muhammad Abduh yang mengatakan:

"Allah SWT bersumpah, bahwa Dia telah membentuk manusia dalam bentuk yang paling utama dan menatanya sebaik-baik tatanan. Pernyataan ini dikuatkan dengan suatu pengandaian, yaitu apabila manusia melupakan (tidak memanfaatkan) akal yang dijadikan Allah SWT sebagai alat untuk memuliakannya (manusia), maka mereka cenderung memandang dirinya (menempatkannya) pada kedudukan sebagai sejenis hewan belaka, seperti hewan-hewan lainnya. Mereka akan berbuat seperti binatang tanpa dihalangi oleh rasa malu. Bahkan sebagian mereka mengatakan bahwa manusia diciptakan dengan kecenderungan pada kejahatan. Maka untuk menunjukkan sesatnya pandangan ini, Allah SWT berfirman bahwa Dia telah menganugerahkan kepada manusia sebaik-baik fitrah, baik fisik maupun psikis dan memuliakannya dengan akal yang menjadi alat untuk menguasai dan mengatur seluruh alam bumi dan dengan perkenaan Allah SWT, menguak seluruh alam samawi".

Hal ini senada dengan firman Allah:

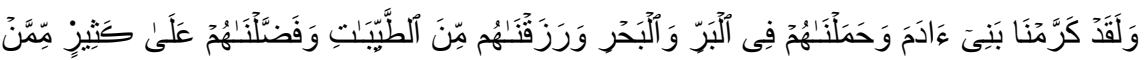

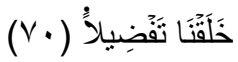

"Dan sesungguhnya telah Kami muliakan anak-anak Adam, Kami angkut mereka di daratan dan di lautan, Kami beri mereka rezki dari yang baik-baik dan Kami lebihkan mereka dengan kelebihan

16Jalal, Abul Fattah, Azas-Azas...,47

Jurnal Pendidikan Agama Islam

Volume 3 Nomor 2 November 2015

ISSN: 2089-1946

Hal. 352 - 367 
yang sempurna atas kebanyakan makhluk yang telah Kami ciptakan".17

Allah SWT telah memuliakan keturunan Adam AS dengan menjadikan mereka mampu memiliki ilmu dengan menggunakan karunia Allah SWT yang tidak lain adalah akal yang mempersiapkan mereka untuk mengemban amanah.

Sesungguhnya akal menjadi tanda kodrati setiap keutamaan dan menjadi sumber setiap adab. Allah SWT menjadikan akal sebagai penopang agama dan tiang dunia. Dengan sempurnanya akal, Allah SWT telah mewajibkan tugas dan dengan hukum-hukum-Nya, Dia menjadikan dunia teratur. Orang yang menggunakan akalnya akan merasa lebih dekat kepada Allah SWT dibanding seluruh orang yang berijtihad tanpa menggunakan akal.18

Di antara kata-kata yang banyak dimuat Al-Qur'an di berbagai tempat adalah kata 'aqala, dalam bentuk fi'il (kata kerja) dan kata al-'aqlu dalam bentuk isim (kata benda). Kiranya hal ini menjadi dalil bahwa yang penting bukanlah sekadar sel-sel yang hidup saja, melainkan akalpun sebagai motor yang menggerakkan perealisasian tugas. Demikianlah Al-Qur'an memberikan aksentuasi kepada salah satu komponen struktur tubuh manusia yang dipandang oleh Islam sebagai sesuatu yang istimewa. Bukankah karena akal ini, permasalahan yang muncul dapat diatasi dan dengan akal pula tugas melaksanakan amanah dapat dipenuhi? Kata-kata yang dijabarkan dari kata 'aqal: 'aqaluhu, ta'qiluna, na'qilu, ya'qiluha dan ya'qiluna dimuat dalam Al-Qur'an, dalam 49 tempat. Sedangkan kata al-albab dalam 16 tempat. Kata al-albab adalah kata jamak dari lubbun yang berarti akal. ${ }^{19}$

Abbas Al-'Aqqad20 berpendapat bahwa; "Al-lubbu adalah akal yang mampu mengetahui dan memahami; akal merupakan sumber pengetahuan dan pemahaman yang terdapat di dalam otak manusia, sebagaimana yang ditujukan oleh namanya dengan Bahasa Arab". Demikian pula di dalam Al-Qur'an terdapat kata Ulin-Nuhā yang berarti 'Orang-orang yang berakal'. Jika kita berbicara di mana saja disebutkan macam-macam tugas akal, seperti berpikir, mengingat, merenung, menimbang dan memandang perkara-perkara, menunjukkan baik dan buruk dan sebagainya, maka kita akan menghadapi sejumlah besar ayat AlQur'an. Akal adalah satu-satunya bagian manusia yang tidak disebutkan oleh AlQur'an dengan namanya secara jelas, tetapi dinyatakan dengan tugasnya.

\footnotetext{
17 Terjemah Al-Qur'an Al-Jumanatul ...,. Al-Isra': 70

${ }^{18}$ Abul Fattah Jalal, Azas-Azas....,57

${ }^{19}$ Yusuf Qardhawi, Al-Qur'an Berbicara...., 24.

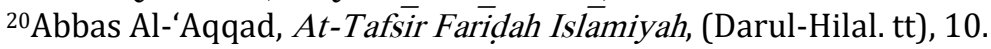


Mengenai akal di dalam Al-Qur'an, Abul Fattah Jalal21 dalam bukunya menyadur perkataan Al-'Aqqad:

"Di antara sedemikian banyak keistimewaan Al-Qur'an, ada satu yang sangat menonjol, yaitu penghormatan terhadap akal serta bersandar kepadanya di dalam masalah 'aqidah dan taklif(tugas). Dalam Al-Qur'an, akal hanya disebut-sebut dalam kedudukannya yang agung sambil diingatkan kepada kewajiban menggunakannya".

Akal pikiran manusia bersifat terbatas di dalam proses belajar yang banyak bergantung pada bimbingan dan petunjuk dari Tuhan. Ditinjau dari aspek belajar, akal pikiran memungkinkan orang untuk menangkap pengertian baik dari ucapan maupun dari tulisan serta mampu pula mengambil kesimpulankesimpulan tentang hukum-hukum yang membentuk susunan dan relasi antar berbagai pengertian yang berbeda. Tidak semua pelajar meninggalkan semua pengertin artificial (semu) belajar dan menggunakan akal pikiran (reasoning) yang asli dalam dirinya sendiri serta memohon bimbingan dari Tuhan yang akan memberi cahaya yang menerangi jalannya sebelum mempelajari hal-hal yang belum diketahui. Walaupun pendapat tersebut lebih sesuai bagi para pelajar tingkat tinggi, namun jelas dapat diambil kesimpulan bahwa dalam proses belajar mengajar (pendidikan) akal pikiran manusia menjadi potensi psikologis yang utama.

Lebih jelasnya untuk memastikan bahwa akal itu bermanfaat, bisa ditempuh melalui pemahaman dedukatif. Sebagai ciptaan, seperti halnya ciptaan yang lain, pastilah akal mempunyai manfaat. Karena Allah SWT tidak menciptakan sesuatu di dunia ini, kecuali ciptaan itu bermanfaat. Yang lebih penting adalah upaya memahami, untuk keperluan apa saja bahwa akal itu bermanfaat? Kiranya pertanyaan tersebut bisa dijawab jika kita menilik konsep akal sebagai alat untuk mencapai kebahagiaan dunia dan akhirat.

Dengan pemahaman tersebut, tidak akan terjadi pemisahan antara ilmu dan kesucian atau takwa. Islam menghendaki ilmu yang suci, ilmu yang diemban oleh ilmuan yang muttaqin, sehingga produk ilmu tidak akan menimbulkan celaka. Sementara itu Islam juga menegaskan bahwa ketakwaan hanya bisa dicapai dengan menggunakan ilmu. Sekedar mengetahui apa yang dimaksud dengan istilah takwa beserta kriterianya harus ditempuh dengan studi yang intensif terhadap Al-Qur'an dan Sunnah Nabi, yang pelaksanaannya tidak mungkin terlepas dari pemakaian prinsip-prinsip ilmu yang relatif sulit.

\footnotetext{
${ }^{21}$ Abul Fattah Jalal, Azas-Azas....,59.

Jurnal Pendidikan Agama Islam

Volume 3 Nomor 2 November 2015

ISSN: 2089-1946

Hal. 354 - 367
} 
Bagaimana orang bisa menuju takwa sedangkan dia belum mengetahui apa itu hakikat takwa. Di sinilah fungsi akal berperan dalam kehidupan manusia. ${ }^{22}$

\section{Fungsi dan Kegunaan Akal}

Begitupun banyaknya fungsi akal bagi manusia, namun akal tidaklah berarti dan tidak akan mendatangkan manfaat jika tidak dididik dan dioptimalkan. Bahkan akal justru harus ditantang dengan berbagai macam ilmu pengetahuan. Islam mengatur seluruh aspek kehidupan manusia, baik dalam urusan-urusan keduniaan maupun yang menyangkut dengan keakhiratan. Pendidikan yang menjadi bagian tak terpisahkan dari ajaran Islam secara keseluruhan, menjunjung tinggi akal pikiran manusia, sehingga dalam dalam prakteknya mampu menunjukkan perbedaan antara manusia dengan makhluk lainnya.

Oleh karena itu, Al-Qur'an memberikan perhatian khusus terhadap penggunaan akal dalam berpikir.

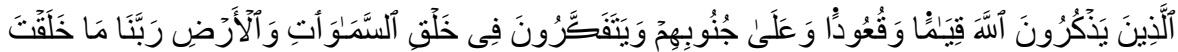

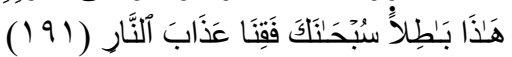

"(yaitu) orang-orang yang mengingat Allah sambil berdiri atau duduk atau dalam keadan berbaring dan mereka memikirkan tentang penciptaan langit dan bumi (seraya berkata): "Ya Tuhan kami, tiadalah Engkau menciptakan ini dengan sia-sia, Maha Suci Engkau, maka peliharalah kami dari siksa neraka". ${ }^{23}$

Islam sebagai sebuah agama yang universal memberikan perhargaan yang tinggi terhadap akal. Tidak sedikit Al-Qur'an dan Hadits Nabi yang menganjurkan dan mendorong manusia untuk mempergunakan akalnya dan banyak berpikir guna mengembangkan intelektualnya. Melalui penggunaan akal itulah manusia dapat mengasah intelek, untuk kemudian menimbulkan sikap kecendekiawan dan kearifan, baik terhadap diri sendiri, masyarakat, maupun terhadap Allah SWT. Dalam Al-Qur'an terdapat kurang lebih 150 ayat mengenai fenomena alam. Ayat-ayat ini disebut kauniyah (kejadian atau kosmos) yang menjelaskan bahwa alam ini penuh dengan tanda-tanda yang harus dipikirkan manusia dan pada akhirnya membawa kepada Tuhan. ${ }^{24}$

\footnotetext{
${ }^{22}$ Anwar, Hanafi, Imam Al Ghazali...,18.

23Terjemah Al-Qur'an Al-Jumanatul ...,. Ali Imron: 191.

${ }^{24}$ Nasution, Harun, Kedudukan ..., 8.
} 
Naufal Ahmad Rijalul Alam

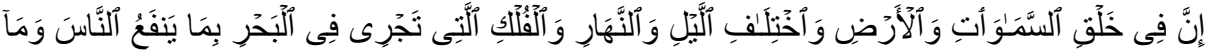

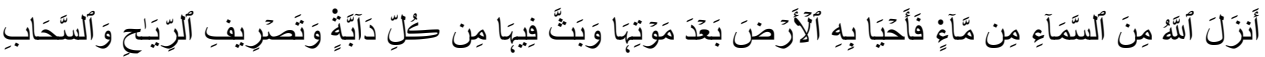

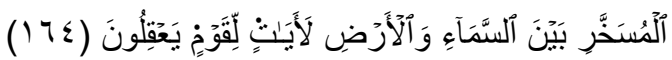

"Sesungguhnya dalam penciptaan langit dan bumi, silih bergantinya malam dan siang, bahtera yang berlayar di laut membawa apa yang berguna bagi manusia, dan apa yang Allah turunkan dari langit berupa air, lalu dengan air itu Dia hidupkan bumi sesudah mati (kering)-nya dan Dia sebarkan di bumi itu segala jenis hewan, dan pengisaran angin dan awan yang dikendalikan antara langit dan bumi; sungguh (terdapat) tandatanda (keesaan dan kebesaran Allah) bagi kaum yang memikirkan".25

Berbicara tentang akal tentunya tidak terlepas dari pembahasan tentang inteligensi atau kecerdasan. Inteligensi ini pada awalnya telah menjadi perhatian utama bagi kalangan ahli psikologi pendidikan. ${ }^{26}$ Sebagaimana Suharsono dalam bukunya (Akselerasi Inteligensi) menyadur pernyataan Conny Semiawan yang mengikhtisarkan berbagai pengertian dan definisi tentang kecerdasan dari para ahli tersebut ke dalam tiga kriteria, yakni judgment (penilaian), comprehension (pengertian) dan reasoning (penalaran), yang kemudian dikritisi oleh A. Anastasi dengan menganggapnya sebagai pembatasan atas ekspresi individu. ${ }^{27}$

Apa yang perlu diketahui adalah bahwa inteligensi merupakan kadar kemampuan seseorang dalam menyerap pada hal-hal yang sifatnya fenomenal, faktual dan data serta hitungan yang kesemuanya tercermin dalam alam semesta. Namun pembelajaran dalam pendidikan manusia untuk meningkatkan inteligensi, tidak mendorong untuk bersyukur kepada Allah SWT, atas penciptaan alam semesta dan manfaat yang bisa diperoleh darinya. ${ }^{28}$

Al-Qur'an memberikan kedudukan yang istimewa kepada akal. Islam menjadikan berpikir sebagai satu keharusan atas semua manusia. Berpikir dianggap sebagai bentuk ibadah yang tertinggi. Perkara ini dapat dilihat melalui firman Allah SWT surat Ali Imran ayat 191 yang telah disebutkan di atas. Demikian juga kita dapat melihat pandangan Islam yang begitu tinggi terhadap penggunaan akal pikiran yang membawa kepada perkembangan sains dan teknologi. Pemikiran ini seterusnya membawa kepada keyakinan tentang

\footnotetext{
25 Terjemah Al-Qur'an Al-Jumanatul ..., Al-Baqarah: 164.

${ }^{26}$ Abror, Abd. Rachman, Psikologi Pendidikan, (Yogyakarta: Tiara Wacana, 1993), 48.

${ }^{27}$ Suharsono, Akselerasi Inteligensi Optimalkan IQ, EQ \& SQ, (Jakarta: Inisiasi Press, 2004), 167. 28Ibid., 167-168.
}

Jurnal Pendidikan Agama Islam

Volume 3 Nomor 2 November 2015

ISSN: 2089-1946

Hal. 356 - 367 
kewujudan dan keagungan Allah SWT. Hal tersebut adalah sebagaimana telah disebutkan dalam surat Al-Baqarah ayat $164 . .^{29}$

Sebagaimana akal adalah kelebihan yang diberikan Allah SWT kepada manusia yang dengannya manusia dapat membuat hal-hal yang dapat mempermudah urusan mereka di dunia. Namun, segala yang dimiliki manusia tentu ada keterbatasan-keterbatasan sehingga ada pagar-pagar yang tidak boleh dilewati. Sains dan teknologi yang merupakan cermin dari kepemilikan IQ, pada awalnya sangat membantu hidup manusia di dunia ini. Tetapi dalam dua dekade terakhir ini, seperti dikatakan oleh Suharsono ${ }^{30}$ dengan menyadur perkataan Fritjof Capra:

"Manusia di seluruh dunia telah dihadapkan pada krisis multidimensional yang belum pernah terjadi sebelumnya. Biang dari semua itu adalah penanganan yang keliru terhadap sains dan teknologi. Sains dan teknologi dalam aspeknya yang parsial memang berguna, tetapi setiap manusia di dunia sekarang ini tak ada yang merasa aman dari ancaman sains dalam bentuknya sebagai senjata nuklir".

Alam yang merupakan "tata gelar" kehidupan manusia di dunia pun mengalami pergeseran-pergeseran peran yang serupa. Alam tak lagi bersahabat, begitu kata sejumlah seniman, karena perlakuan kita yang semena-mena terhadapnya. Mengapa semua ini bisa terjadi? Semua ini terjadi karena superioritas IQ (Intelligence Qutient) yang dimiliki umat manusia pada kenyataannya tidak dibarengi dengan pertumbuhan EQ (Emotional Quotient) maupun SQ (Spiritual Quotient). Ibaratnya IQ adalah bentuk kecerdasan itu sendiri, sementara kandungannya adalah SQ. Ketika SQ kosong dalam diri manusia, maka perannya digantikan oleh emosi dan kesombongan yang mengakibatkan kehancuran bagi semua. Dalam bahasa Al-Qur'an dikatakan bahwa barang siapa menolak pengajaran dari Tuhan, maka dia akan dikendalikan oleh setan.

Meskipun Islam sangat memperhatikan dan memuliakan akal, tetapi tidak lantas menyerahkan segala sesuatu kepada akal, bahkan Islam membatasi ruang lingkup akal sesuai dengan kemampuannya, karena akal terbatas jangkauannya, tidak akan mungkin bisa menggapai hakikat segala sesuatu. Maka Islam memerintahkan akal agar tunduk dan melaksanakan perintah syar'i walaupun belum sampai kepada hikmah dan sebab dari perintah itu.

${ }^{29}$ Yusuf Qardhawi, Al-Qur'an Berbicara...., 27.

${ }^{30}$ Suharsono, Akselerasi....., 59. 
Pengkultusan kepada akal adalah sumber semua kerusakan di alam semesta, akal dijadikan hakim bagi semua perkara, jika datang syari'at yang tidak dipahami oleh akal, maka syari'at itu akan ditolak. Dengan pengkultusan pada akal inilah, maka manusia menolak seruan para Rasul, karena para Rasul mengajak manusia untuk mendahulukan wahyu diatas semua akal dan pemikiran, maka terjadilah pertarungan di antara para pengikut rasul dan para penentangnya.

\section{Pandangan Al-Ghazali tentang Pendidikan Akliah}

Al-Ghazali menjelaskan; "Akal adalah sumber ilmu pengetahuan tempat terbit dan sendi-sendinya. Dalam ilmu pengetahuan itu berlaku dari akal, sebagaimana berlakunya buah-buahan dari pohon, sinar dari matahari dan penglihatan dari mata". 31

Terlebih lagi Al-Ghazali menjelaskan bahwa akal adalah tempatnya ilmu, dan pikiran adalah kunci cahaya dan tempat dimulainya pengetahuan. ${ }^{32}$ Akal pikiran sebagai instrumen pengetahuan dan pengetahuan tentang wahyu, merupakan pembimbing kebenaran agamawi. Akal dan pikiran keduanya adalah saling membutuhkan.

Al-Ghazali menamakan akal sebagai indera keenam yang ada dalam jiwa. Akal adalah sari pati jiwa, sedangkan nafsu dan amarah hanyalah sifat-sifat tambahan. Akal adalah sifat malaikat. Mengikuti tradisi filsafat beliau membuktikan bahwa akal adalah esensi manusia; hakikat setiap jenis adalah sesuatu yang khas bagi jenis itu. Sedangkan sesuatu yang khas pada manusia adalah akal, jadi tentulah akal yang merupakan ciri terpentingnya. ${ }^{33}$ Tugasnya adalah mengetahui realitas di luar indera dan konsekuensi-konsekuensi perbuatan.

a. Tingkatan Akal

Bahwa akal adalah sumber ilmu pengetahuan, teknologi dan kebudayaan, dengan akal dapat dipergunakan untuk menemukan dan menciptakan alat-alat yang berguna untuk menghadapi problem-problem kehidupan manusia. Manusia memerlukan alat dan sarana untuk makan, berpakaian, perumahan, kesenangan jasmani dan rohani. Nazariyah segala karya manusia inilah yang disebut kebudayaan.

Dalam kitab Mi'yarul Ilmi, Al-Ghazali menjelaskan pengertian akal masing-masing menurut terminologyjumh $\overline{u r}$ (mayoritas ulama) dan

\footnotetext{
${ }^{31} \mathrm{Al}-\mathrm{Ghazali}$, Ihya' ‘...Juz I. 82.

${ }^{32} \mathrm{Al}$-Ghazali, Ihya' '...Juz IV. 449.

${ }^{33}$ K. Zurayk, (ed.), Tahdhìb al-Akhlā, (Beirut, 1968), 12.
} 
terminology para filosof. Al-Ghazali menyebutkan tiga pengertian akal menurut jumhürdan delapan pengertian menurut para filosof yang masingmasing kemudian dijelaskannya satu persatu. ${ }^{34}$ Al-Ghazali sendiri tidak menegaskan pengertian mana yang dipilihnya.

Namun di dalam kitab Ihya'nya Juz I tentang hakikat akal dan pembagiannya, Al-Ghazali menjelaskan empat pengertian akal, dengan pengertian yang bertingkat tanpa menjelaskan menurut pengertian siapa, sehingga nampaknya itu merupakan pendapatnya sendiri. Keempat pengertian yang bertingkat itu adalah:

1) Akal adalah suatu sifat yang membedakan manusia dari segala binatang. Akal bersedia menerima berbagai macam ilmu pengetahuan yang nadhariah dan mengatur pekerjaan-pekerjaan yang ringan dan mudah pemikirannya.

2) Hakikat akal adalah ilmu pengetahuan yang tumbuh pada anak usia tamyiz, yaitu dapat membedakan kemungkinan hal yang mungkin dan kemustahilan hal yang mustahil. Seperti mengetahui dua lebih banyak dari satu dan orang tidak pada dua tempat dalam waktu yang sama. Para teolog mendefinisikan akal ini sebagai ilmu daruri, yaitu pengetahuan yang bersifat niscaya, tidak perlu penalaran teoritis dalam penerimaannya.

3) Hakikat akal adalah ilmu pengetahuan yang diperoleh dari pengalaman dengan berlangsungnya berbagai keadaan, maka orang yang telah diperkokoh pemahamannya oleh pengalaman-pengalaman dan ditambah pengetahuannya dengan berbagai madhab (paham), orang tersebut sebagai berakal. Menurut para filosof, akal dalam pengertian ini disebut sebagai akal teoritis (nazarí). ${ }^{35}$

4) Hakikat akal adalah puncak kekuatan tahammus (semangat) untuk mengetahui akibat dari segala persoalan dan mencegah hawa nafsu, yang mengajak pada kesenangan seketika dan mengendalikan syahwat tersebut.

Akal dan kemauanlah yang memberikan karakteristik bagi manusia. Dengan akal pikiran dapat memberikan kepada manusia ilmu pengetahuan yang dipakainya sebagai pedoman dalam usaha dan aktivitas hidupnya, sedangkan kemauanlah yang menjadi pendorong perbuatan manusia. Dengan demikian, antara pendorong perbuatan dan pedoman perbuatan (usaha dan aktivitas hidup) terdapat hubungan saling mempengaruhi (interaction) yang erat sekali.

${ }^{34}$ Jahja, Zurkani. Teologi Al-Ghazali, (Yogyakarta: Pustaka Pelajar, 1996), 126.

35Ibid., 126. 
b. Fungsi Akal

Perlu diketahui bahwa elemen manusia menurut asal fitrahnya memang diciptakan dalam keadaan kosong, artinya sama sekali tidak memiliki pengetahuan tentang beberapa alam Allah SWT. Untuk mengetahui alam diperlukan perantara dan perangkat inteligensi. Permulaan sekali yang Allah SWT ciptakan dalam diri manusia adalah indera peraba, sehingga dengannya manusia dapat mengetahui berbagai jenis perkara yang terdapat di sekitarnya, seperti panas, dingin, basah dan lain-lain. ${ }^{36}$

Kemudian setelah itu Allah SWT menciptakan indera penglihatan, sehingga dengannya manusia bisa mengetahui warna-warna dan beberapa bentuk. Indera ini adalah lebih luas jangkauannya daripada peraba. Setelahnya Allah SWT menciptakan indera perasa yang dengannya manusia dapat merasakan manis, pahit, kecut dan lain-lain sampai manusia benarbenar melewati batas alam inderawi. Dalam proses selanjutnya Allah SWT menciptakan manusia sebagai penyandang predikat "Tamyiż, yaitu masa sekitar umur tujuh tahun yang merupakan periode lain daripada sekian periode keberadaannya di dunia ini. Dalam periode ini manusia bisa mengetahui perkara-perkara yang melebihi apa yang pernah dia kenal dalam alam inderawi.

Selepas itu manusia beranjak naik kepada periode lain, sehingga pada akhirnya Allah SWT menciptakan bagi manusia itu sebuah akal. Dengan akal inilah manusia dapat mengetahui berbagai perkara wajib, jaiz dan perkaraperkara yang mustahil serta langkah-langkah yang belum pernah dia temui pada periode-periode sebelumnya. ${ }^{37}$

Akal mengetahui kenyataan-kenyataan di dunia ini dan di akhirat yang tidak dapat ditangkap oleh indera. Akal juga mengetahui akibat dari suatu perbuatan, jika akibatnya baik, maka kemauan untuk berbuat itu lahir dari dalam pikiran. ${ }^{38}$ Diri manusia mengandung beberapa unsur pokok tertentu, yang mendapatkan tabiatnya menjadi sumber semua perilaku dan kualitas mental. Unsur-unsur ini berbaur dalam susunan tubuhnya (khilqa, tarkib, thina) sedemikian sehingga kita tidak mungkin bebas sepenuhnya dari unsur itu, hanya dengan upaya moral dan perjuanganlah manusia dapat merdeka dari pengaruh jahatnya. Tiap unsur punya pengaruh pada diri manusia, dan karena unsur itu ada empat, maka tabiat yang terdapat pada diri manusia empat pula banyaknya. ${ }^{39}$ Tabiat ini tidak sama dengan tabiat yang asal atau

\footnotetext{
${ }^{36}$ Al-Ghazali, Al-Munqidh Min Al-Dalāl, terj. Marzuqi Aqmal, (Gresik: Putra Pelajar, t.t), 69.

37Ibid., 69.

${ }^{38}$ Al-Ghazali, Ihyā, Juz III, 7-8.

${ }^{39}$ Quasem, M. Abul. Etika Al-Ghazali, (Bandung: Pustaka, 1998), 42.
} 
fitrah, karena fitrah merujuk pada keadaan jiwa saat penciptaannya, sedangkan yang disebut tabiat di sini adalah keadaan setelah lahir.

Keempat unsur itu berkembang tidak serentak, namun secara bertahap. Unsur yang pertama tumbuh adalah unsur kebinatangan, yaitu syahwat. Maksudnya di sini adalah mencari ikhtiar, sehingga badan yang merupakan kendaraan bagi jiwa akan tetap sehat dan agar makhluk manusia tidak musnah. Syahwat inilah yang bertanggungjawab terhadap sifat kebinatangan pada manusia, seperti makan, tidur dan bersenggama. 40

Unsur kedua adalah kebuasan, yaitu amarah. Kegunaannya sebagai pengusir semua hal yang merugikan bagi jasad. Karena unsur ini, manusia memiliki sifat dan perilaku binatang buas, seperti iri, keganasan dan sifat bertengkar. Kalau tidak dikendalikan, kedua unsur ini akan menyebabkan kehancuran moral. Tapi pada beberapa manusia, unsur-unsur ini diciptakan dengan kadar yang sedang-sedang saja dan ini adalah karunia Allah SWT bagi mereka.

Setelah itu pada usia di mana kemampuan membeda-bedakan mulai timbul (tamyiz), yakni kira-kira umur tujuh tahun, unsur kesyaitanan muncul. Ini dari usaha penggunaan kemampuan membeda-bedakan tersebut untuk keperluan mencari jalan menuju kejahatan dan untuk memuaskan amarah dan gairah melalui penipuan dan muslihat licik. Unsur inilah yang bertanggung jawab terhadap perilaku dan sifat tercela manusia seperti permusuhan, mengajak orang kepada yang jahat, bermegah-megahan dan sebagainya. Hal ini tidak begitu menonjol pada orang-orang yang diciptakan dengan tingkat nafsu dan amarah yang berkadar sedang. Alasan inilah yang menyebabkan Rasulullah SAW, bahwa setan yang ada di dalam tubuh beliau telah menyerah kepada beliau. Selain unsur kesyaitanan dalam susunan tubuh manusia, ada pula wujud syaitan yang di luar tubuh manusia, yang menggiringnnya kepada kejahatan dengan merangsang nafsu dan amarah serta memberinya anjuran-anjuran jahat. ${ }^{41}$

Unsur yang terakhir muncul dalam diri manusia adalah unsur ketuhanan, sumber sifat-sifat cinta akan pujian, kekuasaan dan pengetahuan berbagai disiplin ilmu. Unsur ini ada pada jiwa sejak saat penciptaannya. Karena sifatnya yang rabbani, jadi unsur ini selalu mengejawantah. Keempat unsur di atas dipaparkan Al-Ghazali dalam dua tempat pada kitab Ihya, di satu tempat tidak disebutkan perihal akal, ${ }^{42}$ tetapi di tempat yang lain, meskipun akal disinggung di samping empat unsur tersebut, nampaknya akal disamakan

40Ibid., 43.

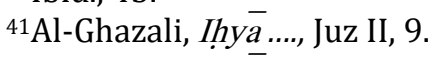

${ }^{42} \mathrm{Al}$-Ghazali, Ihya ...., Juz IV, 14.

Jurnal Pendidikan Agama Islam Volume 3 Nomor 2 November 2015 
dengan unsur ketuhanan. ${ }^{43}$ Namun dalam Arba'in, nampak jelas bahwa akal adalah kekuatan tersendiri yang berkembang setelah pengejawantahan unsur ketuhanan; ${ }^{44}$ akal mulai muncul pada usia di mana seorang anak mulai bisa membeda-bedakan, kemudian berkembang tahap demi tahap pada usia baligh dan menjadi sempurna pada umur empat puluh tahun, ketika manusia menjadi orang dewasa sepenuhnya.

Telah dijelaskan di atas bahwa dalam diri manusia terdapat nafsu dan amarah yang keduanya bisa menjadi sesuatu yang berfaedah sepanjang dalam batas-batas yang wajar. Namun sering kali keduanya selalu cenderung melampaui batas, sangat suka memberontak dan benar-benar irasional. ${ }^{45}$ Nafsu dan amarah ini sering dirangsang oleh iblis sehingga keduanya dinamakan kaki tangan setan. Akallah yang tahu batas-batas yang pantas dan akibat-akibat jeleknya jika melampaui batas, tugasnyalah memerintahkan hawa nafsu agar tetap dalam batas tersebut. Karena itu akal disebut kaki tangan Allah SWT dan juga neraca-Nya di bumi; dan melakukan itu semua demi membantu persiapan jiwa di akhirat. ${ }^{46}$

Namun demikian, akal tidak selalu mempunyai daya untuk mencegah hawa nafsu yang telah melewati batas. Tatkala akal berkembang pada saat manusia mencapai kematangannya, didapati hawa nafsu telah kuat sekali dalam jiwa, karena nafsu berkembang jauh lebih dulu dan telah menjadi bertambah kuat dengan seiring dicapainya kepuasan. Karena hawa nafsu benar-benar irasional, dia tidak bisa patuh pada akal. Diperlukan suatu kekuatan untuk memaksakan perintah akal kepada hawa nafsu dan menjaganya agar tetap terkendali.

Melihat pernyataan-pernyataan Al-Ghazali tentang akal di atas, nampaknya beliau tidak memberikan definisi tentang akal secara teoritis, namun beliau lebih mengungkapkan definisi akal melalui pendekatan kegunaan, yakni manfaat akal itu sendiri. Perlu digaris bawahi juga bahwa dalam pemikiran beliau tentang akal terdapat sedikit kontradiksi antara pernyataan yang satu dengan lainnya.

Kontradiksi tersebut nampak dalam pernyataannya tentang akal dalam kitab Ihya Ulumiddin dan dalam kitab Arba'in. Sebagaimana telah disebutkan di atas, dalam kitab Ihya Ulumiddin, beliau memandang akal sebagai esensi dari unsur ketuhanan dalam diri manusia, sedangkan dalam kitab Arba'in, beliau memandangnya sebagai kekuatan tersendiri setelah

\footnotetext{
${ }^{43} \mathrm{Al}-\mathrm{Ghazali}$, Ihyā...., Juz III, 9-10.

${ }^{44}$ Quasem, M. Abul. Etika....., 43.

${ }^{45}$ Al-Ghazali, Kimiya'i Sa'adat, (Teheran, 1319 H), 15.

46Ibid., 16.
} 
unsur ketuhanan yang telah mengejawantah. Namun begitu, kontradiksi tersebut tidaklah menjadi kendala dalam mendefinisikan akal melalui pendekatan kegunaan.

\section{E. Pendidikan Akliah}

Beberapa pengertian akal sebagaimana dijelaskan di atas dapat dipahami bahwa Al-Ghazali sangat menghormati akal pikiran manusia dan menempatkan ilmu pengetahuan pada tempat yang mulia dalam peradaban dan kebudayaan dengan sistemnya yang universal. ${ }^{47}$ Oleh karena itu segala ilmu pengetahuan harus diselidiki sedalam-dalamnya, dikembangkan dan disebarluaskan sehingga merata kepada seluruh umat manusia. Dengan demikian aspek pendidikan akliah merupakan keharusan sebagaimana memuliakan akal pikiran manusia dan hasil tafakkurnya. Kemudian Al-Ghazali lebih mendahulukan ilmu pengetahuan daripada ibadah, dengan berkata, "Ilmu lebih mulia daripada ibadah. Tetapi ibadah merupakan buah dari ilmu. Ilmu tidak berfaedah jika tidak menghasilkan ibadah, pohon tidak berguna kalau tidak berbuah, dua-duanya harus ada, akan tetapi ilmu lebih dahulu".48

Statemen Al-Ghazali itu patut disimak bahwa ilmu pengetahuan yang diperoleh dengan akal pikiran harus lebih didahulukan. Bukan satu-satunya jalan untuk memperoleh ilmu pengetahuan adalah dengan mempelajari buku-buku, bacaan-bacaan maupun menghafal pengertian semata-mata. Mempelajari dan memperoleh ilmu pengetahuan dapat ditempuh melalui berbagai macam cara, seperti dengan metode percobaan, pengalaman, penelitian dan mempelajari alam sekitarnya atau bahkan berrtafakkur tentang alam semesta. Hal tersebut adalah sebagaimana dikatakan oleh Al-Ghazali:

"Marilah kita pilih yang mudah dipikirkan, yaitu dapat kita lihat dengan mata kepala; langit, bumi dan apa saja yang ada di kolong langit, dengan bintang-bintangnya dapat kita lihat, mataharinya, gerakannya dan rotasi peredarannya, tentang terbit dan terbenamnya. Demikian juga bumi dapat kita lihat dengan gunung-gunung, tambang, sungai, lautan, binatang-binatang dan tumbuhan-tumbuhannya. Apa yang ada di kolong langit itu, udara dapat kita lihat awannya, hujannya, geledek, kilat, halilintar, meteorit, angin topan dan sebagainya". ${ }^{49}$

Peristiwa-peristiwa tersebut adalah keajaiban alam semesta atau sunnatullah, sebagai ayat-ayat kauniyah yang menjadi tanda-tanda kekuasaan

\footnotetext{
47 Zainuddin, Seluk-Beluk Pendidikan dari Al-Ghazali, (Jakarta: Bumi Aksara. 1991), 120.

${ }^{48}$ Al-Ghazali, Minhajul ' $\bar{A}$ bidin, terj. Abul Hiyadh, (Surabaya: Mutiara Ilmu, 1995), 17

${ }^{49} \mathrm{Al}-\mathrm{Ghazali}$, Ihyā...., Juz IV, 461.
} 
dan kebesaran Allah SWT. Oleh Al-Qur'an, kita sangat dianjurkan untuk memikirkannya dan mengadakan penelitian sehingga dapat ditemukan berbagai macam ilmu pengetahuan di abad modern ini. Lewat ayat-ayat kalamiyah dan kauniyah-Nya, Allah SWT banyak menantang umat manusia untuk supaya berpikir dan merenung.

Hasil dari tafakkur adalah ilmu pengetahuan, keadaan dan amal. Ilmu merupakan buah yang terutama, bila ilmu sudah masuk ke dalam hati, maka berubahlah keadaan hati. Dan bila keadaan hati sudah berubah, maka berubah pula amal perbuatan anggota badan. Jadi amal itu bergantung pada keadaan dan keadaan bergantung pada ilmu, sedangnkan ilmu bergantung pada tafakkur. Kesimpulannya, tafakkurlah yang menjadi prinsip-prinsip dari segala kebaikan.50

Demikian tinggi fungsi berpikir yang digambarkan oleh Al-Ghazali, sehingga akal pikiran tidak akan menjadi cerdas dan berguna, selama akal pikiran tidak diperkenalkan, dipergunakan dan bahkan ditantang dengan berbagai macam ilmu pengetahuan. Antara berpikir, ilmu pengetahuan dan amal perbuatan adalah "Interpendensis" (saling menggantungkan) dan "Komplementer" (saling melengkapi) sehingga dapat mencapai kebaikan yang sempurna. Meskipun Al-Ghazali tidak banyak memperhatikan dan membahas pendidikan akliah dibandingkan dengan pembahasannya dalam bidang pendidikan akhlak, - sehingga beliau lebih terkenal dalam bidang pendidikan akhlak - namun bukan berarti beliau mengesampingkan pendidikan akliah.

Namun begitu, meskipun Islam sangat memperhatikan dan memuliakan akal, tetapi tidak menyerahkan segala sesuatu kepada akal, bahkan Islam membatasi ruang lingkup akal sesuai dengan kemampuannya, karena akal terbatas jangkauannya, tidak akan mungkin bisa menggapai hakikat segala sesuatu. Maka Islam memerintahkan akal agar tunduk dan melaksanakan perintah syar'i walaupun belum sampai kepada hikmah dan sebab dari perintah itu.

Al-Ghazali sendiri menjelaskan bahwa untuk mencapai sifat pertengahan antara baik dan buruk, kekuatan akal dan syari'ah adalah sebagai faktor penuntun. ${ }^{51}$ Juga dalam kitab Arba'in dan Kimiya', Al-Ghazali menjelaskan bahwa akal dan syari'ah sebagai pengendali atas nafsu dan amarah.

Himbauan Al-Ghazali yang berulang-ulang untuk menggunakan akal dan syari'ah bagi penentuan sifat pertengahan ini mencerminkan pengaruh ajaran Islam pada dirinya - Al-Qur'an seringkali menyuruh manusia berpikir merenungkan, agar mereka bisa memahami kebenaran yang ada di dalamnya. Sifat pertengahan itu biasanya relatif, berbeda antara orang yang satu dengan

50Ibid.,121.

${ }^{51}$ Al-Ghazali, Ihyā...., Juz III, 46.

Jurnal Pendidikan Agama Islam

Volume 3 Nomor 2 November 2015

ISSN: 2089-1946

Hal. 364 - 367 
orang yang lain, dan malah berbeda pada seorang pribadi dalam keadaan yang berlainan. ${ }^{52}$

Melalui uraian di atas, menurut hemat penulis Al-Ghazali sendiri berada dalam posisi yang tepat ketika menjelaskan konsep pendidikan akal dengan menyatakan bahwa untuk mencapai sifat pertengahan antara baik dan buruk, kekuatan akal dan syari'ah adalah sebagai faktor penuntun mengingat akal pikiran bukanlah satu-satunya problem solver tertinggi bagi manusia.

Bukankah ajaran Islam sendiri menganjurkan setiap orang untuk memikirkan kejadian langit dan mengamati alam semesta, menghayati dan memikirkan setiap persoalan dan peristiwa yang terdapat dalam ala mini, supaya meyakini terhadap kebesaran, kekuasaan dan kesempurnaan Allah SWT yang menjadikan dan mengatur semuanya, sehingga semakin sadarlah dia akan kelemahan dirinya di hadapan Allah SWT. Hal ini berarti bahwa akal tidak boleh melampaui batas-batas yang diberikan oleh Allah SWT, yakni batas-batas yang diajarkan oleh agama Islam melalui syari'ah-Nya.

Hakikat konsep pendidikan akliah menurut Al-Ghazali bukanlah sekedar ide yang tanpa pembuktian. Konsep ini dihasilkan dari pemikiran kritis dan logis terhadap penanggulangan penyakit-penyakit rohani. Hal ini dibuktikan oleh AlGhazali melalui kisah hidupnya yang syarat dengan pengalaman-pengalaman kerohanian. Salah satunya adalah ketika beliau mengalami krisis rohani setelah menjadi tokoh intelektual dengan menjabat sebagai rektor Universitas Nidhomiyah di Baghdad. Beliau mengatakan:

"Aku lihat diriku tenggelam dalam samudra godaan dan rintangan. Segala perjalananku yang terbaik adalah mengajar dan mendidik kutinjau sedalam-dalamnya. Jelas kau sedang memperhatikan beberapa ilmu yang tidak penting untuk perjalanan akhirat. Apa niat dan tujuanku dengan mengajar dan mendidik, nyatalah tidak murni kepada Allah Ta'ala melainkan dicampuri oleh pengaruh ingin kedudukan dan kemashuran. Maka terserahlah kepadaku bahwa aku berdiri di pinggir jurang yang curam, di atas tebing terjal yang hampir gugur. Aku akan jatuh ke neraka jika tidak segera merubah sikap". ${ }^{3}$

Dari sinilah penulis menganalisa bahwa Al-Ghazali memandang akal tidaklah menjadi satu-satunya alat untuk mencapai kebahagiaan di dunia dan akhirat, namun yang lebih penting adalah bagaimana manusia mampu menyeimbangkan antara kegunaan akal dan kebenaran wahyu.

Meskipun konsep yang dipaparkan oleh Al-Ghazali ini nampak hanya sebagai bimbingan dan penyuluhan, namun bila mengingat akan perkembangan

52Ibid., Juz III, 84.

${ }^{53}$ Al-Ghazali, Mutiara Ihya Ulumiddin, terj. H. Rus'an, (Semarang: Wicaksana, 1985), 12. 
ilmu pengetahuan sekarang yang terkesan sekuler oleh sebab hegemoni Barat dengan munculnya suatu masa yang disebut Renaissance setelah masa The Dark Ages yang disebut sebagai masa di mana alam pikiran telah mati karena belenggu gereja (agama), maka konsep ini tepat sekali. Dengan adanya konsep ini dan meskipun dikatakan kurang sempurna bagi dunia pendidikan, Al-Ghazali telah lebih dulu mencetuskan konsep pendidikan akal dalam arti pengoptimalan akal itu sendiri dibandingkan dengan konsep-konsep yang dicetuskan oleh tokohtokoh pendidikan kontemporer, hanya saja beliau juga menambahkan peran agama.

\section{F. Penutup}

Dari uraian di atas, secara teoretis filosofis penulis mencoba menyimpulkan bahwa pendidikan akliah dalam pandangan Al-Ghazali adalah pendidikan dalam rangka mengoptimalkan akal pikiran dengan memberikan menu secara proporsional dan seimbang antara sains dan teknologi dengan pengetahuan akan alam metafisika, tentunya dengan berlandaskan ajaran-ajaran agama Islam yang bersumber dari Al-Qur'an dan Al-Hadits. Penulis kembali memberikan kesimpulan bahwa mendidik dan mengoptimalkan akal pikiran dapat dilaksanakan dengan hal-hal di bawah ini: 1) Menggali, menyelidiki dan mengkaji berbagai macam ilmu pengetahuan secara intens dan akurat, 2) Mengamati fenomena alam untuk mengetahui sebab-sebab di baliknya, 3) Mengisinya dengan berbagai macam ilmu yang bersifat fardhu 'ainmaupun yang bersifat fardhu kifayah, 4) Tidak menafikan kebenaran wahyu untuk terus mendampingi langkah-langkah kemajuan akal. Upaya-upaya intelektual dan spiritual yang sunguh-sungguh inilah yang mampu mengundang campur tangan Ilahi dalam bentuk inspirasi dan kilasan-kilasan kreatif yang sangat berarti bagi kehidupan manusia.

\section{G. Daftar Pustaka}

Abror, Abd. Rachman. Psikologi Pendidikan, Yogyakarta: Tiara Wacana, 1993.

Ahmadi, Abu dan Umar, M. Psikologi Umum (edisi revisi), Surabaya: PT Bina Ilmu. 1990.

Al-'Aqqad, Abbas, At-Tafsir Farìidah Islamiyah, Darul-Hilal. tt. Al-Ghazali. Al-Munqidh min Al-Dalal, Istanbul: Darussefaka, 1981. Al-Munqidhmin Al-Dalal, terj. Marzuqi Aqmal, Gresik: Putra Pelajar. tt. Ihya' 'Ulumiddin, Juz I, II, III, IV, Isal Babiyul Hilbi wa Syirkah. tt. . Kimiya'i Sa'adàt, Teheran, $1319 \mathrm{H}$. . Mutiara Ihya Ulumiddin, terj. H. Rus'an, Semarang: Wicaksana, 1985. . Minhajul 'Ābidin, terj. Abul Hiyadh, Surabaya: Mutiara Ilmu, 1995. Anwar, Hanafi. Imam Al Ghazali; Hikmah Berpikir, Gresik: Putra Pelajar,1998. 
Arifin, H.M. Filsafat Pendidikan Islam, Jakarta: Bumi Aksara, 2000.

Ashraf, Ali. Horison Baru Pendidikan Islam, Jakarta: Pustaka Firdaus, 1989.

Azra, Azyumardi. Esei-Esei Intelektual Muslim \& Pendidikan Islam, Jakarta: Logos. 1999.

Bakri, Umar. Tafsir Al-Madrasi, Juz 1, Ponorogo: Percetakan Darussalam Gontor. 2000.

Daradjat, Zakiah, dkk. Ilmu Pendidikan Islam, Jakarta: Bumi Aksara. 1992.

Jalal, Abul Fattah. Azas-Azas Pendidikan Islam, Bandung: CV. Diponegoro. 1988.

Jahja, Zurkani. Teologi Al-Ghazali, Pustaka Pelajar, Yogyakarta, 1996

Nasution, Harun. Kedudukan Akal dalam Islam, Jakarta: Idayu. 1988.

Qardhawi, Yusuf. Al-Qur'an Berbicara tentang Akal dan Ilmu Pengetahuan, Jakarta: Gema Insani Press. 1998.

Quasem, M. Abul . Etika Al-Ghazali, Pustaka, Bandung. 1998.

Suharsono. Akselerasi Inteligensi Optimalkan IQ, EQ \& SQ, Jakarta: Inisiasi Press. 2004.

Terjemah Al-Qur'an, Al-Jumanatul Ali, CV. Penerbit J-Art, 2004.

Zainuddin, Seluk-Beluk Pendidikan dari Al-Ghazali, Jakarta: Bumi Aksara. 1991.

Zurayk, K., (ed.), Tahdzib al-Akhlaq, Beirut, 1968 